local " door to door" recruitment drives. A publisher has printed free of charge: "The History of the Norwegian Red Cross 1865-1965".

The authorities are also obliging. A charming example: the Red Cross emblem in flowers will appear during the summer season in public parks all over the country, and as far as feasible, on local stations along the State railway lines. The postal authorities are going to issue Centenary postage stamps in two current values, bearing the Red Cross emblem.

The main event, and the climax, will be the solemn observance of the 100th anniversary of the foundation of the Norwegian Red Cross on 22nd September in the Aula of the Oslo University.

One thing is certain : no effort will be spared, no opportunity missed. And, in addition, to make " Every Norwegian a Member of the Red Cross", we shall endeavour to make better known and understood the ideas and ideals of the Red Cross.

\title{
A PUBLICATION ON THE INTERNATIONAL RED CROSS CENTENARY CONGRESS
}

The International Committee, the League and the Swiss Red Cross organized in 1963 the Centenary Congress of the International Red Cross in Geneva. This was attended by delegates from 88 National Societies of the Red Cross, Red Crescent and Red Lion and Sun, as well as by representatives of the ICRC and the League.

The Centenary Commission of the Red Cross in Switzerland issued a publication containing the speeches delivered on the Commemorative Day, September 1, 1963, at the Grand Theatre in Geneva, as well as the address given by Mr. Carl J. Burckhardt, former President of the ICRC, entitled " The Red Cross Spirit " and which readers of the Reviere will have found already in our issue of December 1963. This publication ${ }^{1}$ is well presented and illustrated

${ }^{1}$ Centenary Congress of the International Red Cross: Geneva, $10 \mathrm{frs}$. Orders may be sent to the ICRC, Geneva. 


\section{IN THe Red Cross World}

and also gives the gist of the proceedings of the Council of delegates which took place in the United Nations building from September 2 to 10,1963 , and which was attended by many representatives of National Societies, the ICRC and the League. Also included are the 25 resolutions adopted by the Council of Delegates and which cover a wide range of humanitarian subjects. This publication of 120 full-size pages is available in English and French.

It will be recalled that the Centenary Commission of the Red Cross in Switzerland has issued several publications, each of which has been mentioned in the Review 1 .

\section{THE RED CROSS AND FIRST-AIDERS}

It is common knowledge that first-aid is one of the basic activities of the Red Cross Societies and it was for this reason that an International Meeting of first-aiders was held on August 19, 1963, at Macolin, Switzerland, as one of the Red Cross Centenary events. It was attended by 150 participants from 37 National Societies and the main part of its programme consisted of a comparison and discussion of first-aid techniques and training.

The results are dealt with in a report by the Centenary Commission of the International Red Cross ${ }^{2}$. It includes illustrations of the transport and care of casualties and also gives a description of artificial respiration and heart massage techniques. It was noticeable, at Macolin, that almost all basic principles of first-aid are the same for every National Society, the differences which exist being concerned more particularly with details of the manner of application and, moreover, that it is desirable to draw up and disseminate on a world scale a series of conventional signs repre-

1 The titles of these publications are :

a) International Red Cross Meeting of First-Aiders.

b) World Conference of Educators.

Both were published in Geneva in French, English and Spanish.

2 Published in Geneva under the title International Red Cross Meeting of First-Aiders; it is No. 25 in the League's series on medico-social work and has been published in French, English and Spanish. 